\title{
THE IDEA OF EFFECTIVE INTERNATIONAL LAW: CONTINUING THE DISCUSSION
}

\author{
Vijay Padmanabhan*
}

The joint 108th American Society of International Law (ASIL) Annual Meeting and 76th International Law Association (ILA) Biennial Conference was organized under the theme "The Effectiveness of International Law." In conjunction with this theme, the ASIL Legal Theory Interest Group hosted a panel discussion ${ }^{1}$ exploring the theoretical dimensions of the concept of "effectiveness" as understood in international law. Panelists discussed three related questions:

(1) Is the effectiveness of international law an empirical question measured through evaluating compliance with international legal norms?

(2) What conceptions of effectiveness might exist beyond compliance? Could such conceptions be captured in theoretical or moral terms?

(3) Why is international law concerned with effectiveness at all?

In this week's AJIL Unbound symposium, the contributors build upon the discussion of these questions at the ASIL-ILA joint meeting, in the process shedding new light on the concept of effectiveness. In the first post, Professor Timothy Meyer of the University of Georgia explains why it is inappropriate to conflate compliance with the effectiveness of international law. Meyer argues that an excessive focus on compliance is likely to understate the effectiveness of international law, where international law is understood to be "effective" if it causes a change in State behavior. In many instances, for example, claims that States are not complying with their international legal obligations are merely attempts to negotiate the meaning of unclear international law - a process that is actually effective if it impacts State behavior.

The second contribution, by Professor Liam Murphy of New York University, contemplates four meanings that might be attributed to the term "effectiveness." First, Murphy defends the traditional link between effectiveness and compliance: international law matters only if it affects actual behavior. Second, he agrees with Meyer that a more accurate measure of international law's effectiveness lies in whether it induces State compliance. But such a measure is more theoretical than empirical because of the difficulties in measuring motivation. This reality leads Murphy to suggest that effectiveness is best understood in terms of enforcement, meaning international law is effective if it possesses the institutions and sanctions needed to coerce States to comply. Such an approach focuses international actors on reforms needed to improve State compliance with international law. Lastly, he argues that these approaches to effectiveness should not overlook whether international law provides moral reasons to comply. International law may be effective if it provides reasons other than self-interest for State action.

* Assistant Professor of Law at the Vanderbilt University Law School.

Originally published online 17 June 2014.

${ }^{1}$ Gary J. Shaw, The Idea of Effective International Law, ASIL CABLES (Apr. 11, 2014). 
The third post, by Professor Jean D'Aspremont of the University of Manchester and the University of Amsterdam, engages fully with the third question: why do international lawyers care whether law is effective? After all, international law may be useful as an expression of the values of the international community irrespective of whether those values are acted upon. D'Aspremont explains that international lawyers are not satisfied with viewing international law as merely ideas, but rather take comfort in viewing it as conditioning the world around them. This real world impact convinces international legal academics and practitioners that they are more than mere theologians. But he cautions that this sense of effectiveness is in some ways deceitful because it may imply a degree of control over the outside world that is beyond the power of international law.

Together, this set of essays casts new light on a continuing debate among international lawyers and academics as to whether international law is effective and why that matters. In hosting this panel and online symposium, the ASIL Legal Theory Interest Group wishes to spark further discussion regarding these issues, especially through comments on AJIL Unbound. Our hope is that a better definition of effective international law is an important legacy of the 2014 ASIL-ILA joint meeting. 